parallel to the introduction of cultivated plants, he could use the old records in the British Museum for his purpose, and he began to write his last book, "The Botany of Cook's Voyages". Unfortunately he was taken ill and the work was interrupted; he recovered and resumed it, but was taken ill again. At a second resumption he completed the writing, and with the help of others the book was published in the autumn of 1954, by which time he was exceedingly ill; but he lived to February 25 of this year. He had received many honours and had obtained an international position in his own branch of botany that was unmatched. I. H. BuRkILL

\section{Sir Cyril Norwood}

WIтH the death of Sir Cyril Norwood on March 13, at the age of eighty, there passed an outstanding figure in the world of education of the past fifty years. His influence was comparable to that of men like Arnold in the nineteenth century. Norwood, a brilliant classical scholar from Merchant Taylors' School, gained the highest honours at Oxford and spent several years in the Home Civil Service before entering the teaching profession at Leeds Grammar School in 1901. Five years later he became head. master of Bristol Grammar School, and during fifteen years he transformed its standards and achievements. Then followed nine years, perhaps the zenith of his school activities, as master of Marlborough College, before his migration to the headmastership of Harrow and in 1934 to the presidency of St. John's, Oxford, his former College, from which he resigned in 194.6 because of his wife's ill-health.

Throughout his whole educational career, Dr. Norwood brought what has been called the 'modern approach' to bear upon the organization concerned. Without relinquishing his firm belief both in the value of a classical training for the study of language and in the study of ancient history, he was among the first to emphasize the need for a greater emphasis on the teaching of modern languages, geography, science, and later of economics. His underlying aim seemed to be to modify where necessary an existing system of education-sometimes stereotyped or stagnant-so as to meet the needs of a changing world or society, and the present arrangement of the General Certificate of Education examinations owes much to the analysis of the Norwood Report of 1943 . The vast impact of the sciences, pure and applied, during the post-war years, came a little too late for him to play an active part; but it might have been interesting indeed to see his outlook upon it.

Norwood had a strong, compelling, even if at times enigmatic personality. In appearance he might have been likened to Lord Kitchener, and the methods of the two men were at times similar. His deep religious beliefs were matched by a conviction of the essential correctness and desirability of his educa. tional policies. This caused him at times to appear despotic and ruthless. He brought criticism upon himself from some by the widespread publicity he gave to his ideas. Yet he did not deliberately seek the publieity which followed as a result of the innate conviction of his mission and his desire for progress. The value of his work was proved by the successes of his pupils and masters alike. His reserve, possibly a shyness, made him appear unapproachable to many; but others learnt to know him as a kindly, human personality and a friend of good counsel. Of all the talks which he gave throughout his life, few could have surpassed in simple, penetrating eloquence that which he delivered in the chapel of his College on the cessation of war in 1945. For him, too, it was to be the epilogue of a life filled with interest and achievement.

\section{Dr. Robert Pohi}

OVER a period of fully half a century, developments in the design of rotating electrical machines have been influenced by the work of Dr. Robert Pohl, whose death occurred on March 15. He was seventy. seven years of age.

Born at Hamm, Westphalia, Pohl received his university education at Hanover and his first industrial experience with the firm of Lahmeyer in Frank. furt. At the time at which Pohl entered the electrical industry, direct-current practice was well established and the utilization of alternating current was undergoing intensive developmerit. The dynamo was already an efficient and relatively refined machine awaiting only the devising of means further to improve its commutation. Pohl's first contribution to the advancement of electrical knowledge, made when he was little more than a student, was towards elucidat. ing the mode of action of the interpole or commutating pole then newly invented.

Pohl went to England in 1904 to join the staff of the Phoenix Dynamo Co. of Bradford, and he was appointed chief engineer of the Company at the age of twenty-eight. He was responsible for the produetion by that Company of the first machine with commutating poles to be built in Great Britain. From 1905 onwards Pohl contributed, except for the period of the First World War, to the literature of electrical machinery. His more important early papers were on direct-current machines, but by 1914 he was writing on turbo-alternators.

Six months after the outbreak of the First World War Pohl was interned. He returned to Germany in 1919, where he became director and chief engineer of the A.E.G. Turbine Works in Berlin. More than thirty papers, published for the most part in ElektroTechnische Zeitschrift and Elektrotechnik und Maschinenbau between 1919 and 1938, record the contributions which placed Pohl in the first rank of designers of large electrical machines. He made one of the early experiments in the hydrogen cooling of alternators, running $a$ machine in town's gas in Charlottenburg. By 1938 it had become clear to Pohl that he and his family could not much longer escape Nazi persecution. Through the good offices of friends he was able to get away safely to England and was joined by his wife and son. Prof. William Cramp was instrumental in securing the appointment of Pohl to the staff of his department in the University of Birmingham.

The third phase of Pohl's career was to prove no less fruitful than the first two. He brought to his teaching a wealth of practical experience, and he had the power to transmit his ideas. The British ThomsonHouston Co. retained him as a consultant, and it was not long before contributions from his pen began again to appear in the Journal of the Institution of Electrical Engineers. This time, inductor alternators and the behaviour of magnetic material in machines claimed much of his attention.

At the time of his retirement from the University of Birmingham Pohl was serving as a consultant in 